\title{
Normal Vibrations of Polyglycine II
}

\author{
YASUAKI ABE and S. KRIMM,* Harrison M. Randall Laboratory of \\ Physics and Macromolecular Research Center, University of Michigan \\ Ann Arbor, Michigan 48104
}

\section{Synopsis}

A valence force field has been refined for single-chain polyglycine II using the known structure and four isotopic derivatives. The calculated frequencies are in good agreement with the observed. The force field is compared with that derived from polyglycine I and for the nylons.

\section{INTRODUCTION}

Normal coordinate calculations of polyglycine II (PG II) have been carried out by Miyazawa and Tsuchida, ${ }^{1,2}$ Small, Fanconi, and Peticolas, ${ }^{3}$ and Singh and Gupta. ${ }^{4}$ In these calculations, however, only one or two isotopic molecules were treated and/or the $\mathrm{CH}_{2}$ group was replaced by a single mass.

We have recalculated the normal vibrations of five isotopic species of the PG II chain in the crystal without replacing the $\mathrm{CH}_{2}$ group by a single mass, and have determined a valence force field in a manner similar to that for the polyglycine I (PG I) crystal in the preceding paper. ${ }^{5}$ The results are presented herein.

\section{CALCULATION OF NORMAL VIBRATIONS}

Structure. The X-ray study of Crick and Rich ${ }^{6}$ indicated that PG II is a threefold helical chain which is hydrogen bonded via $\mathrm{N}-\mathrm{H} \cdots \mathrm{O}=\mathrm{C}^{\prime}$ bonds to adjacent chains in the crystal. A small modification regarding the packing of chains was subsequently proposed by Ramachandran, Sasisekharan, and Ramakrishnan. ${ }^{7}$ In this modified structure one third of the $\mathrm{C}^{\prime}=0$ groups are also involved in a $\mathrm{C}-\mathrm{H} \cdots \mathrm{O}=\mathrm{C}^{\prime}$ hydrogen bond. Evidence for such hydrogen bonds was presented in the infrared studies of Krimm, Kuroiwa, and Rebane. ${ }^{8,9}$ It was also noted ${ }^{10}$ that antiparallel chain arrangements must exist in the crystal. This requirement was subsequently incorporated into a revised crystal structure. ${ }^{11}$

The present calculations were done for the parallel-chain structure. The unit cell in this case contains one chain, and thus a single-chain treat-

* To whom correspondence should be addressed. 
ment was adopted. The results are probably very similar for antiparallel chain arrangements. The same structural parameters as given in Table I of the preceding paper ${ }^{5}$ were used. The repeat of the helix is $9.30 \AA$, which corresponds to bond rotation angles of $\varphi(\mathrm{N}-\mathrm{C})=-76.89^{\circ}$ and $\psi\left(\mathrm{C}-\mathrm{C}^{\prime}\right)=145.32^{\circ}$.

Coordinates and Selection Rules. The internal coordinates and the local symmetry coordinates were defined in the same way as in Tables II and III of the preceding paper, ${ }^{5}$ except for the interchain coordinates which were not considered here.

The optically active symmetry coordinates are classified into two species, $\mathrm{A}$ and $\mathrm{E}$, and are given by

$$
\begin{aligned}
\mathbf{S}(\mathrm{A}) & =C \sum_{i}\left(\mathbf{S}_{\mathrm{I}}^{i}+\mathbf{S}_{\mathrm{II}}^{i}+\mathbf{S}_{\mathrm{III}}^{i}\right) \text { for the A species }(\delta=0), \\
\mathbf{S}^{c}(\mathrm{E}) & =C^{\prime} \sum_{i}\left(2 \cdot \mathbf{S}_{\mathrm{I}}^{i}-\mathbf{S}_{\mathrm{II}}^{i}-\mathbf{S}_{\mathrm{III}}^{i}\right), \quad \text { and } \\
\mathbf{S}^{S}(\mathrm{E}) & =C^{\prime \prime} \sum_{i}\left(\mathbf{S}_{\mathrm{II}}^{i}-\mathbf{S}_{\mathrm{III}}^{i}\right) \text { for the } \mathrm{E} \text { species }\left(\delta= \pm^{2} / 3 \pi\right),
\end{aligned}
$$

where $\mathbf{S}_{\mathrm{I}}^{i}, \mathbf{S}_{\mathrm{II}}^{i}$, and $\mathbf{S}_{\mathrm{III}}^{i}$ are the vectors consisting of the local symmetry coordinates for the three repeating units, as designated by I, II, and III in Figure 1, of the $i$ th unit cell, $\delta$ is the phase angle between neighboring units along a helix, and the $C^{\prime}$ 's are normalization coefficients. The sums are taken over unit cells along a helix. $\mathbf{S}^{c}(\mathrm{E})$ and $\mathbf{S}^{S}(\mathbf{E})$ are a pair of real symmetry coordinates for the degenerate species with $\delta= \pm^{2} / 3 \pi$, by use of which all numerical calculations can be carried out using real numbers. ${ }^{12}$ There are nineteen $\mathrm{A}$ species modes and twenty $\mathrm{E}$ species modes, all of these being both Raman- and infrared-active.

Valence Force Field. The valence force field of PG II was defined in the same way as for PG I. Since calculations were made for a single chain, seventy-two intrachain force constants out of the seventy-eight constants listed in Table $\mathrm{V}$ of the preceding paper were considered here.

The observed frequencies used for adjusting the force constants are considered not to involve the effects of $\mathrm{CH} \cdots \mathrm{O}=\mathrm{C}^{\prime}$ hydrogen bonding. All chains, however, are assumed to be involved in $\mathrm{N}-\mathrm{H} \cdots \mathrm{O}=\mathrm{C}^{\prime}$ hydrogen bonding. Therefore, the effects of the latter type of hydrogen bonding are included in the seventy-two intrachain force constants. Although such hydrogen bonding effects depend on temperature, ${ }^{9}$ the force constants determined in the present work correspond to those at room temperature.

Adjustment of Force Constants. The force constants were adjusted so that they give the best fit with the infrared spectra of $-\mathrm{NHCH}_{2} \mathrm{CO}$-, $-\mathrm{N}^{15} \mathrm{HCH}_{2} \mathrm{CO}-,-\mathrm{NDCH}_{2} \mathrm{CO}-,-\mathrm{NHCD}_{2} \mathrm{CO}-$, and $-\mathrm{NDCD}_{2} \mathrm{CO}-$ reported by Suzuki, Iwashita, Shimanouchi, and Tsuboi ${ }^{13}$ and the Raman bands reported by Small et al. ${ }^{3}$

The assignments of the observed bands adopted here are almost the same as those of previous workers. ${ }^{1,3,4,13}$ Minor modifications were made 

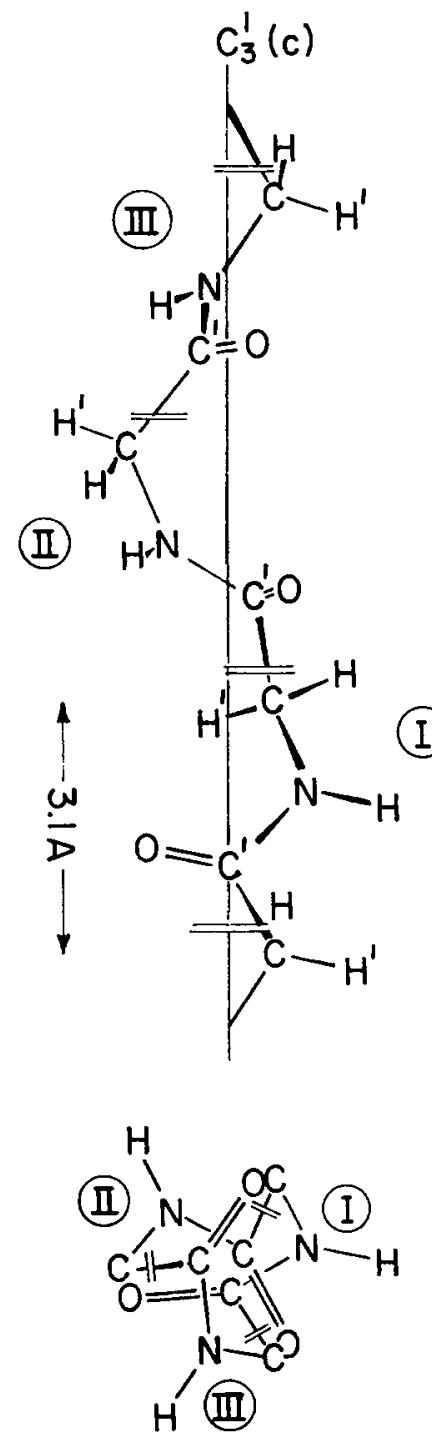

Fig. 1. Structure of the polyglycine II chain.

according to preliminary calculations. For example, the infrared band at $901 \mathrm{~cm}^{-1}$ and the Raman band at $884 \mathrm{~cm}^{-1}$ of $-\mathrm{NHCH}_{2} \mathrm{CO}-$, which had been assigned to the $\mathrm{CH}_{2}$ rocking vibrations, were reassigned to the symmetric stretching vibration of the $\mathrm{N}=\mathrm{C}=\mathrm{O}$ skeleton. This assignment is consistent with the fact that the $884 \mathrm{~cm}^{-1}$ Raman band is very strong. The assignment of each band to either the $\mathrm{A}$ or the $\mathrm{E}$ species was made in such a way that all the assignments were consistent for all the isotopic molecules. 
TABLE I

Force Constants of PGII, PGI, and Nylons

\begin{tabular}{|c|c|c|c|}
\hline & PGII & $\mathbf{P G I}^{\mathrm{a}}$ & Nylons $^{14}$ \\
\hline 1. $f(\mathrm{~N}-\mathrm{C})^{\mathrm{b}}$ & $4.855(0.109)^{c}$ & 5.025 & 5.278 \\
\hline 2. $f\left(\mathrm{C}-\mathrm{C}^{\prime}\right)$ & $4.513(0.216)$ & 4.419 & 5.174 \\
\hline 3. $f\left(\mathrm{C}^{\prime}-\mathrm{N}\right)$ & $6.741(0.330)$ & 6.304 & 6.117 \\
\hline 4. $f\left(\mathrm{C}^{\prime}=0\right)$ & $9.167(0.184)$ & 9.496 & 8.780 \\
\hline 5. $f(\mathrm{~N}-\mathrm{H})$ & $5.992(0.023)$ & 5.998 & 5.98 \\
\hline 6. $f(\mathrm{C}-\mathrm{H})$ & $4.569(0.012)$ & 4.564 & 4.545 \\
\hline 7. $f\left(\mathrm{C}^{\prime} \mathrm{NC}\right)$ & $0.806(0.160)$ & 1.050 & 1.475 \\
\hline 8. $f\left(\mathrm{NCC}^{\prime}\right)$ & 1.00 & 1.00 & $1.028^{* \mathrm{~d}}$ \\
\hline 9. $f\left(\mathrm{CC}^{\prime} \mathrm{N}\right)$ & $1.40 \dagger$ & 1.40 & 1.045 \\
\hline 10. $f\left(\mathrm{CC}^{\prime}=0\right)$ & $1.218(0.111)$ & 1.269 & 1.331 \\
\hline 11. $f\left(\mathrm{NC}^{\prime}=\mathrm{O}\right)$ & & & 1.495 \\
\hline 12. $f\left(\mathrm{C}^{\prime} \mathrm{NH}\right)$ & $0.575(0.010)$ & 0.496 & 0.848 \\
\hline 13. $f(\mathrm{CNH})$ & & & 0.306 \\
\hline 14. $f(\mathrm{NCH})$ & $0.810(0.039)$ & 0.699 & $0.728^{*}$ \\
\hline 15. $f\left(\mathrm{C}^{\prime} \mathrm{CH}\right)$ & $0.693(0.034)$ & 0.673 & $0.694^{*}$ \\
\hline 16. $f(\mathrm{HCH})$ & $0.533(0.014)$ & 0.588 & $0.553^{*}$ \\
\hline 17. $f\left(C^{\prime}=0\right.$ op $)$ & $0.562(0.036)$ & 0.614 & 0.70 \\
\hline 18. $f(\mathrm{~N}-\mathrm{H} \mathrm{op})$ & $0.206(0.024)$ & 0.191 & 0.114 \\
\hline 19. $f(\mathrm{~N}-\mathrm{C}$ tor $)$ & 0.037 & 0.037 & 0.037 \\
\hline 20. $f\left(\mathrm{C}-\mathrm{C}^{\prime}\right.$ tor $)$ & 0.037 & 0.037 & 0.037 \\
\hline 21. $f\left(\mathrm{C}^{\prime}-\mathrm{N}\right.$ tor $)$ & $0.604(0.061)$ & 0.598 & 0.671 \\
\hline 22. $f\left(\mathrm{~N}-\mathrm{C}, \mathrm{C}-\mathrm{C}^{\prime}\right)$ & 0.3 & 0.3 & 0.091 \\
\hline 23. $f\left(\mathrm{C}-\mathrm{C}^{\prime}, \mathrm{C}^{\prime}-\mathrm{N}\right)$ & 0.3 & 0.3 & 0.638 \\
\hline 24. $f\left(\mathrm{C}^{\prime}-\mathrm{N}, \mathrm{N}-\mathrm{C}\right)$ & 0.3 & 0.3 & 0.352 \\
\hline 25. $f\left(\mathrm{C}-\mathrm{C}^{\prime}, \mathrm{C}^{\prime}=\mathrm{O}\right)$ & 0.5 & 0.5 & 0.764 \\
\hline 26. $f\left(\mathrm{C}^{\prime}-\mathrm{N}, \mathrm{C}^{\prime}=\mathrm{O}\right)$ & 0.5 & 0.5 & 0.230 \\
\hline 27. $f\left(\mathrm{C}^{\prime}-\mathrm{N}, \mathrm{C}^{\prime} \mathrm{NC}\right)$ & 0.3 & 0.3 & -0.108 \\
\hline 28. $f\left(\mathrm{~N}-\mathrm{C}, \mathrm{C}^{\prime} \mathrm{NC}\right)$ & 0.3 & 0.3 & 0.615 \\
\hline 29. $f\left(\mathrm{~N}-\mathrm{C}, \mathrm{NCC}^{\prime}\right)$ & 0.3 & 0.3 & 0.312 \\
\hline 30. $f\left(\mathrm{C}-\mathrm{C}^{\prime}, \mathrm{NCC}^{\prime}\right)$ & 0.3 & 0.3 & 0.325 \\
\hline 31. $f\left(\mathrm{C}-\mathrm{C}^{\prime}, \mathrm{CC}^{\prime} \mathrm{N}\right)$ & 0.3 & 0.3 & 0.021 \\
\hline 32. $f\left(\mathrm{C}^{\prime}-\mathrm{N}, \mathrm{CC}^{\prime} \mathrm{N}\right)$ & 0.3 & 0.3 & 0.521 \\
\hline 33. $f\left(\mathrm{C}-\mathrm{C}^{\prime}, \mathrm{CC}^{\prime}=0\right)$ & 0.2 & 0.2 & 0.258 \\
\hline 34. $f\left(\mathrm{C}^{\prime}-\mathrm{N}, \mathrm{NC}^{\prime}=\mathrm{O}\right)$ & 0.2 & 0.2 & 0.084 \\
\hline 35. $f\left(\mathrm{C}^{\prime}=\mathrm{O}, \mathrm{CC}^{\prime}=\mathrm{O}\right)$ & 0.45 & 0.45 & 0.379 \\
\hline 36. $f\left(\mathrm{C}^{\prime}=\mathrm{O}, \mathrm{NC}^{\prime}=\mathrm{O}\right)$ & 0.45 & 0.45 & 0.495 \\
\hline 37. $f\left(\mathrm{C}^{\prime}-\mathrm{N}, \mathrm{C}^{\prime} \mathrm{NH}\right)$ & $0.232(0.036)$ & 0.298 & 0.375 \\
\hline 38. $f(\mathrm{~N}-\mathrm{C}, \mathrm{CNH})$ & $0.401(0.046)$ & & $\begin{array}{l}0.324 \\
0.365\end{array}$ \\
\hline 39. $f(\mathrm{~N}-\mathrm{C}, \mathrm{NCH})$ & $0.401(0.040)$ & 0.520 & 0.365 \\
\hline $\begin{array}{l}\text { 40. } f\left(\mathrm{~N}-\mathrm{C}, \mathrm{C}^{\prime} \mathrm{CH}\right) \\
\text { 41. } f\left(\mathrm{C}-\mathrm{C}^{\prime}, \mathrm{NCH}^{2}\right)\end{array}$ & $0.005(0.039)$ & 0.044 & $\begin{array}{l}-0.109 \\
-0.073\end{array}$ \\
\hline 42. $f\left(\mathrm{C}-\mathrm{C}^{\prime}, \mathrm{C}^{\prime} \mathrm{CH}\right)$ & $0.205(0.062)$ & 0.225 & 0.207 \\
\hline 43. $f\left(\mathrm{C}^{\prime} \mathrm{NC}, \mathrm{NCC}^{\prime}\right)$ & 0.0 & 0.0 & —e \\
\hline 44. $f\left(\mathrm{NCC}^{\prime}, \mathrm{CC}^{\prime} \mathrm{N}\right)$ & 0.0 & 0.0 & - \\
\hline 45. $f\left(\mathrm{CC}^{\prime} \mathrm{N}, \mathrm{C}^{\prime} \mathrm{NC}\right)$ & 0.0 & 0.0 & 0.095 \\
\hline 46. $f\left(\mathrm{NCC}^{\prime}, \mathrm{CC}^{\prime}=\mathrm{O}\right)$ & 0.0 & 0.0 & - \\
\hline 47. $f\left(\mathrm{C}^{\prime} \mathrm{NC}, \mathrm{NC}^{\prime}=0\right)$ & 0.0 & 0.0 & 0.193 \\
\hline 48. $f\left(\mathrm{CC}^{\prime} \mathrm{N}, \mathrm{C}^{\prime} \mathrm{NH}\right)$ & 0.2 & 0.2 & 0.213 \\
\hline 49. $f\left(\mathrm{NCC}^{\prime}, \mathrm{CNH}\right)$ & $-0.1 \dagger$ & -0.1 & 一 \\
\hline
\end{tabular}


TABLE I (continued)

\begin{tabular}{|c|c|c|c|}
\hline & PGII & PGI ${ }^{\mathbf{a}}$ & Nylons ${ }^{14}$ \\
\hline 50. $f\left(\mathrm{C}^{\prime} \mathrm{NC}, \mathrm{NCH}\right)$ & 0.0 & 0.0 & -0.010 \\
\hline 51. $f\left(\mathrm{C}^{\prime} \mathrm{NC}, \mathrm{NCH}^{\prime}\right)$ & 0.0 & 0.0 & -0.010 \\
\hline 52. $f\left(\mathrm{CC}^{\prime} \mathrm{N}, \mathrm{C}^{\prime} \mathrm{CH}\right)$ & 0.0 & 0.0 & -0.023 \\
\hline 53. $f\left(\mathrm{CC}^{\prime} \mathrm{N}, \mathrm{C}^{\prime} \mathrm{CH}^{\prime}\right)$ & 0.0 & 0.0 & -0.023 \\
\hline 54. $f\left(\mathrm{NCH}, \mathrm{NCH}^{\prime}\right)$ & $-0.037(0.030)$ & 0.018 & $-0.013^{*}$ \\
\hline 55. $f\left(\mathrm{C}^{\prime} \mathrm{CH}, \mathrm{C}^{\prime} \mathrm{CH}^{\prime}\right)$ & $0.047(0.033)$ & -0.022 & $0.056^{*}$ \\
\hline 56. $f\left(\mathrm{NCH}, \mathrm{C}^{\prime} \mathrm{CH}\right)$ & $0.093(0.025)$ & 0.022 & $0.033^{*}$ \\
\hline 57. $f(\mathrm{NCH}, \mathrm{HCH})$ & 0.05 & 0.05 & $0.046^{*}$ \\
\hline 58. $f\left(\mathrm{C}^{\prime} \mathrm{CH}, \mathrm{HCH}\right)$ & 0.05 & 0.05 & $0.051^{*}$ \\
\hline 59. $f\left(\mathrm{NC}^{\prime}=\mathrm{O}, \mathrm{C}^{\prime} \mathrm{NH}\right)$ & $0.140(0.046)$ & 0.238 & 0.181 \\
\hline 60. $f\left(\mathrm{CC}^{\prime}=\mathrm{O}, \mathrm{C}^{\prime} \mathrm{CH}\right)$ & $0.1 \dagger$ & 0.1 & 0.132 \\
\hline 61. $f\left(\mathrm{CC}^{\prime}=\mathrm{O}, \mathrm{C}^{\prime} \mathrm{CH}^{\prime}\right)$ & 0.0 & 0.0 & 0.132 \\
\hline 62. $f(\mathrm{CNH}, \mathrm{NCH})$ & $0.077(0.030)$ & 0.076 & 0.056 \\
\hline 63. $f\left(\mathrm{CNH}, \mathrm{NCH}^{\prime}\right)$ & $0.002(0.028)$ & 0.068 & 0.056 \\
\hline 64. $f\left(\mathrm{C}^{\prime}=\mathrm{O}\right.$ op, $\left.\mathrm{NCC}^{\prime}\right)$ & $-0.05 \dagger$ & -0.05 & - \\
\hline 65. $f\left(\mathrm{C}^{\prime}=\mathrm{O} \mathrm{op}, \mathrm{C}^{\prime} \mathrm{CH}\right)$ & $0.1 \dagger$ & 0.1 & 0.04 \\
\hline 66. $f\left(\mathrm{C}^{\prime}=\mathrm{O}\right.$ op, $\left.\mathrm{C}^{\prime} \mathrm{CH}^{\prime}\right)$ & 0.0 & 0.0 & 0.04 \\
\hline 67. $f\left(\mathrm{~N}-\mathrm{H}\right.$ op, $\left.\mathrm{NCC}^{\prime}\right)$ & 0.0 & 0.0 & - \\
\hline 68. $f(\mathrm{~N}-\mathrm{H}$ op, $\mathrm{NCH})$ & 0.0 & 0.0 & 0.00 \\
\hline 69. $f\left(\mathrm{~N}-\mathrm{H}\right.$ op, $\left.\mathrm{NCH}^{\prime}\right)$ & $0.1 \dagger$ & 0.1 & 0.00 \\
\hline 70. $f\left(\mathrm{C}^{\prime}=\mathrm{O}\right.$ op, $\mathrm{N}-\mathrm{H}$ op $)$ & $-0.06 \dagger$ & -0.06 & -0.034 \\
\hline 71. $f\left(\mathrm{C}^{\prime}=\mathrm{O}\right.$ op, $\mathrm{C}^{\prime}-\mathrm{N}$ tor $)$ & $0.07 \dagger$ & 0.07 & 0.162 \\
\hline 72. $f\left(\mathrm{~N}-\mathrm{H}\right.$ op, $\mathrm{C}^{\prime}-\mathrm{N}$ tor $)$ & $-0.08 \dagger$ & -0.08 & -0.034 \\
\hline
\end{tabular}

a Set I-3 of Ref. 5 .

b See Ref. 5 for definitions of these internal coordinates.

- Numbers in parentheses are the uncertainties in the force constants. The values followed by their uncertainties were obtained by least squares, those marked by $\dagger$ were adjusted by trial and error, and the others were transferred from paraffins and amides (see Ref. 5).

d The values marked by * are the averages of the corresponding values for the $\mathrm{CCH}_{2} \mathrm{C}^{\prime}$ and the $\mathrm{NCH}_{2} \mathrm{C}$ groups of nylons.

e - indicates that the force constant cannot be estimated (note there is no $\mathrm{NHC}_{2} \mathrm{C}^{\prime}$ group in nylon- $p$ with $p>2$ ).

The force constants were determined following the same procedure as in the preceding paper, ie, thirty-four force constants were fixed to the same value as the corresponding ones of $P G I$, nine constants were adjusted by trial and error, and twenty-nine constants, of which four pairs were set identical with each other, were refined by least squares.

The final values of the force constants are listed in Table I, together with those of $\mathrm{PG} \mathrm{I}^{5}$ and the nylons ${ }^{14}$ obtained by the single-chain treatment. (Some of the definitions of the coordinates and the force constants adopted in Ref. 14 are different from those in the present work. Their values were modified according to the present definitions and are given in Table I.) The frequencies calculated with the final set of force constants, and the potential energy distributions, are given in Table II. The agreement with the observed frequencies is seen to be quite satisfactory. 
TABLE II

Observed and Calculated Frequencies of Polyglycine II (in $\mathrm{cm}^{-1}$ )

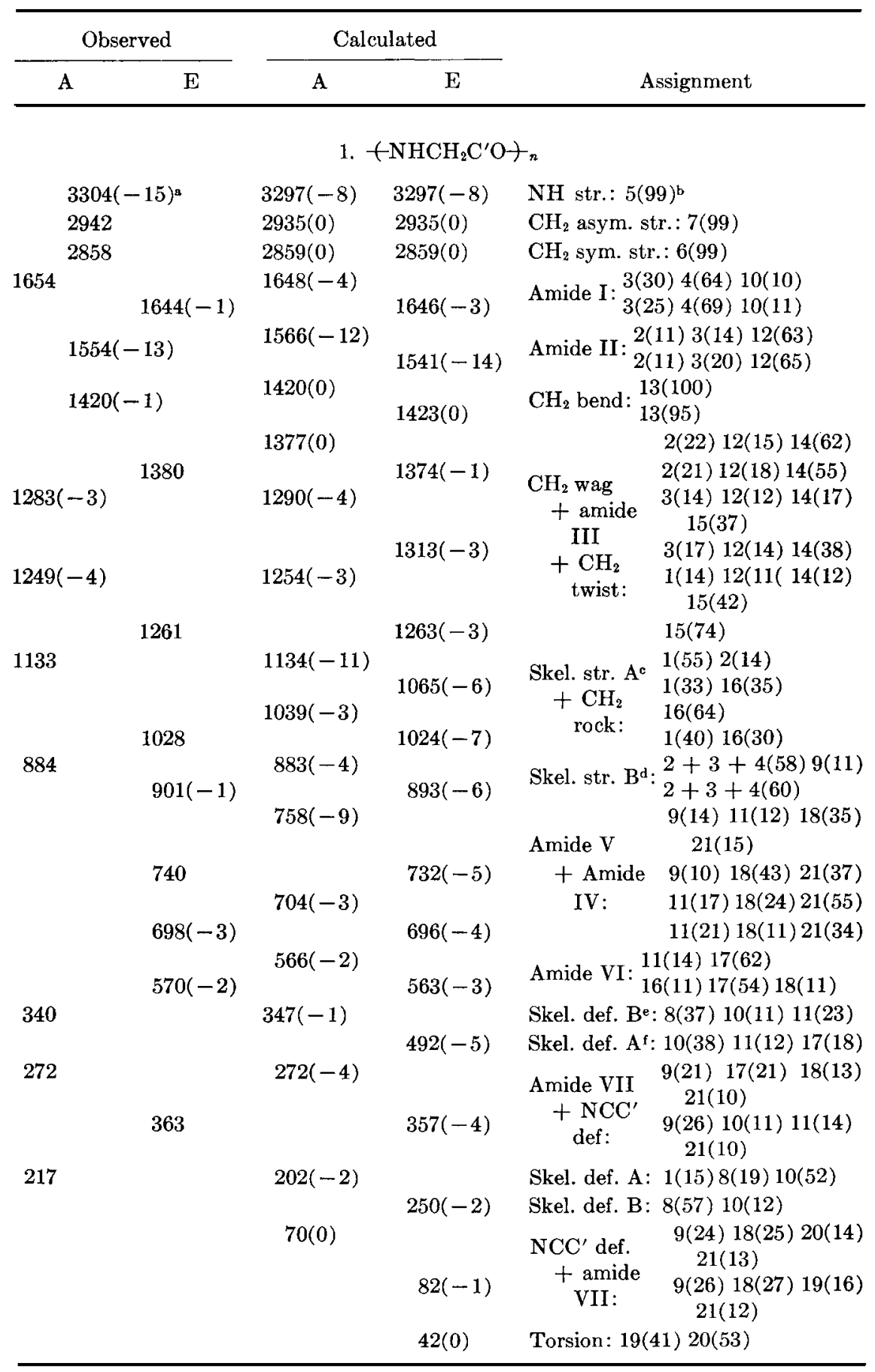


POLYGLYCINE. II

TABLE II (continued)

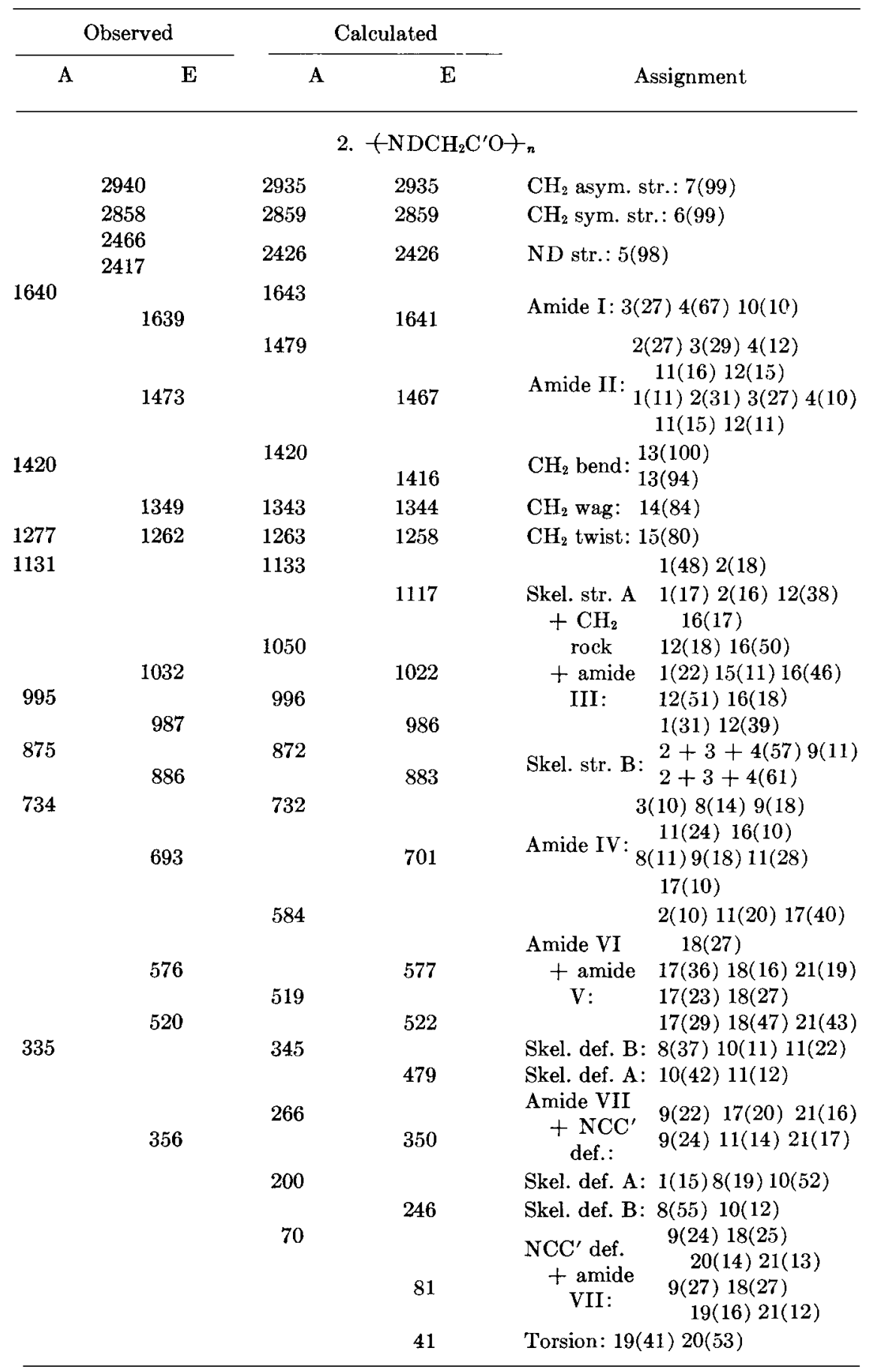


TABLE II (continued)

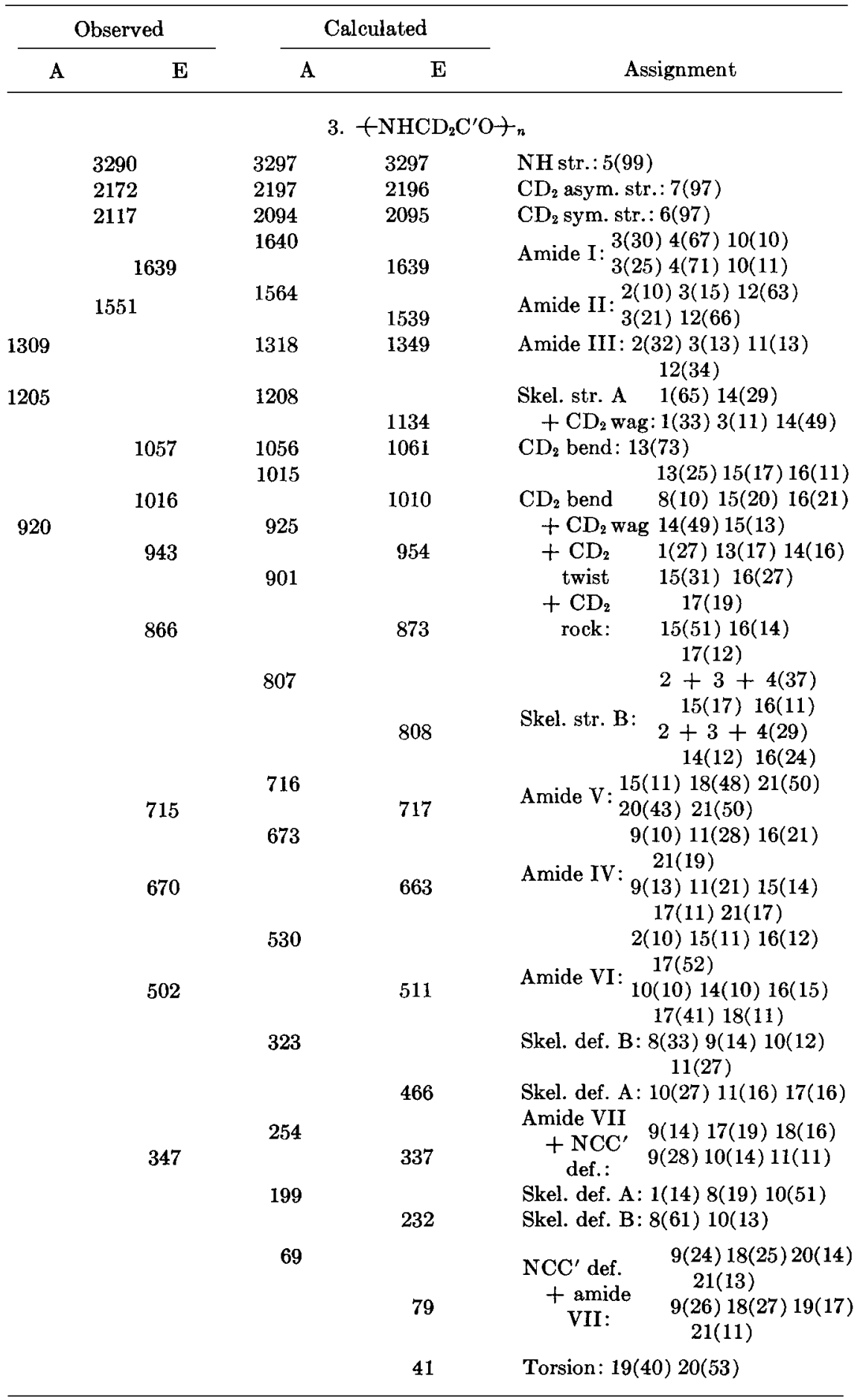


TABLE II (continued)

\begin{tabular}{lllllll}
\hline & \multicolumn{2}{c}{ Observed } & & \multicolumn{2}{c}{ Calculated } & \\
\cline { 1 - 2 } \cline { 5 - 6 } & $\mathrm{E}$ & & $\mathrm{A}$ & $\mathrm{E}$ & & Assignment \\
\hline
\end{tabular}

4. $+\mathrm{NDCD}_{2} \mathrm{C}^{\prime} \mathrm{O} \rightarrow_{n}$

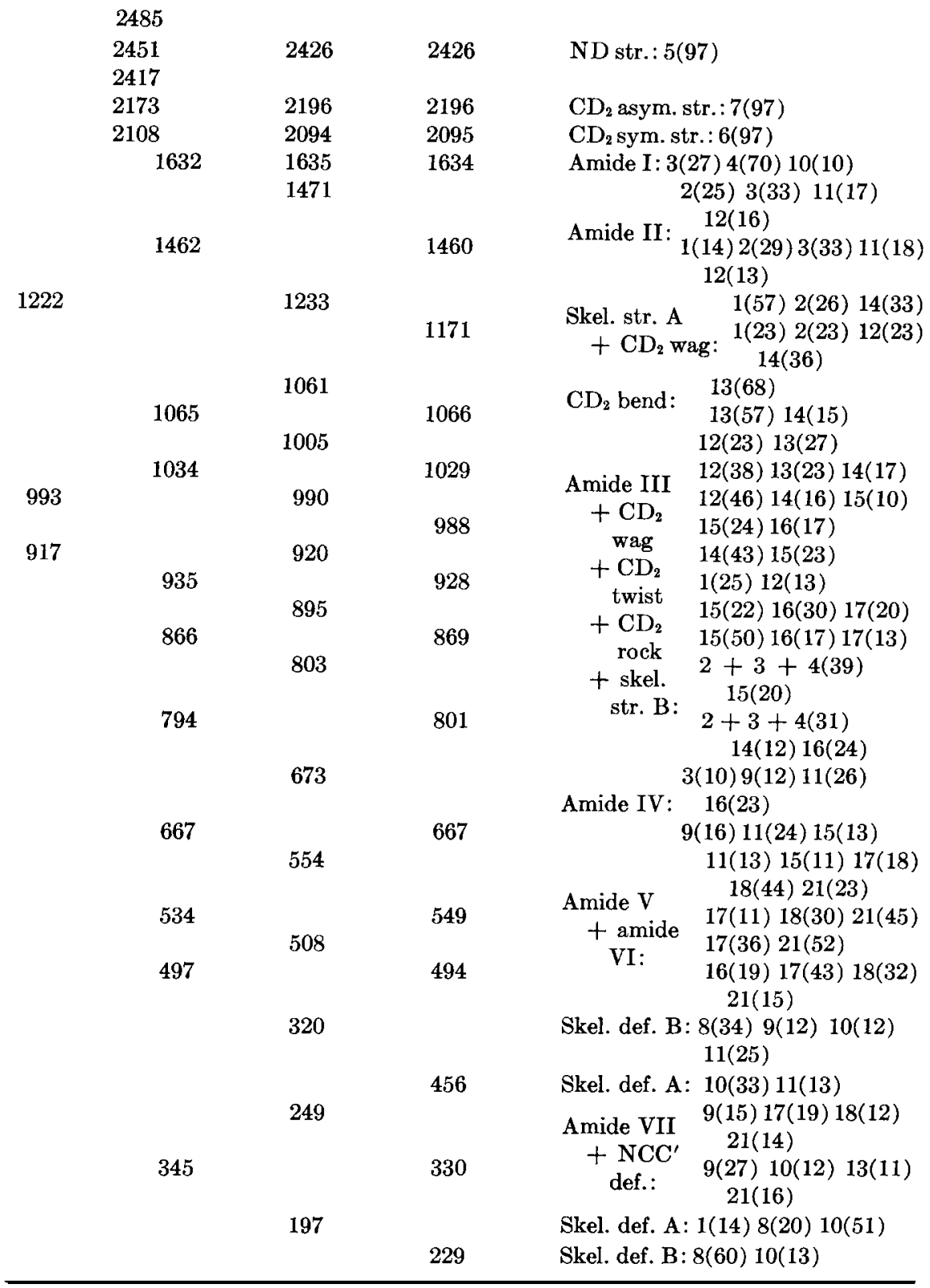


TABLE II (continued)

\begin{tabular}{|c|c|c|c|c|}
\hline \multicolumn{2}{|c|}{ Observed } & \multicolumn{2}{|c|}{ Calculated } & \multirow[b]{2}{*}{ Assignment } \\
\hline A & $\mathbf{E}$ & A & $\mathbf{E}$ & \\
\hline & & 68 & & $\begin{array}{l}\mathrm{NCC}^{\prime} \text { def. } 9(24) 18(25) 20(14) \\
+\quad 21(12)\end{array}$ \\
\hline & & & 78 & $\begin{array}{c}\text { Amide VII: } 9(26) 18(26) 19(17) \\
21(12)\end{array}$ \\
\hline & & & 41 & Torsion: $19(40) 20(53)$ \\
\hline
\end{tabular}

${ }^{a}(\quad)=\nu\left(\mathrm{N}^{16}\right)-\nu\left(\mathrm{N}^{14}\right)$.

b The first number refers to the symmetry coordinate (see Table III of Ref. 5 for a detailed description of these coordinates), the number in parenthesis to the fractional potential energy in this coordinate (if it is 10 or greater). Qualitatively, the symmetry coordinates are: 1: $\mathrm{N}-\mathrm{C}$ str.; 2: $\mathrm{C}^{-\mathrm{C}^{\prime}}$ str.; $3: \mathrm{C}^{\prime}-\mathrm{N}$ str.; 4: $\mathrm{C}^{\prime}=\mathrm{O}$ str.; $5: \mathrm{N}-\mathrm{H}$ str.; 6: $\mathrm{CH}_{2}$ sym. str.; 7: $\mathrm{CH}_{2}$ asym. str.; 8: $\mathrm{C}^{\prime} \mathrm{NC}$ def.; $9: \mathrm{NCC}^{\prime}$ def.; 10: $\mathrm{CC}^{\prime} \mathrm{N}$ def.; 11: $\mathrm{C}=\mathrm{O}$ ip bend; $12: \mathrm{N}-\mathrm{H}$ ip bend; $13: \mathrm{CH}_{2}$ bend; $14: \mathrm{CH}_{2}$ wag; $15: \mathrm{CH}_{2}$ twist; $16: \mathrm{CH}_{2}$ rock; 17: $\mathrm{C}=\mathrm{O}$ op bend; $18: \mathrm{N}-\mathrm{H}$ op bend; $19: \mathrm{N}-\mathrm{C}$ tor; $20: \mathrm{C}-\mathrm{C}^{\prime}$ tor; $21: \mathrm{C}^{\prime}-\mathrm{N}$ tor.

- Skeletal stretch $\mathrm{A}$ is mainly the $\mathrm{N}-\mathrm{C}$ stretching vibration.

${ }^{a}$ Skeletal stretch $\mathrm{B}$ is mainly a symmetric stretching vibration of the $\mathrm{C}-\mathrm{C}^{\prime}-\mathrm{N}$ skeleton.

e Skeletal deformation $\mathrm{B}$ is mainly the $\mathrm{C}^{\prime} \mathrm{NC}$ deformation vibration slightly mixed with the $\mathrm{CC}^{\prime} \mathrm{N}$ deformation.

' Skeletal deformation $\mathrm{A}$ is mainly the $\mathrm{CC}^{\prime} \mathrm{N}$ deformation vibration slightly mixed with the $\mathrm{C}^{\prime} \mathrm{NC}$ deformation.

\section{DISCUSSION}

The potential energy distributions of the modes of PG II show that extensive mixing occurs. In particular, it is seen that for $+\mathrm{NHCH}_{2} \mathrm{C}^{\prime} \mathrm{O}_{n}$ the $\mathrm{CH}_{2}$ wagging and twisting vibrations are mixed with the amide III mode to an even greater extent than in the case of PG I. For other isotopic species amide III is relatively pure (ef, $+\mathrm{NHCD}_{2} \mathrm{C}^{\prime} \mathrm{O}+{ }_{n}$ ) or even more extensively mixed with other modes (ef, $+\mathrm{NDCD}_{2} \mathrm{C}^{\prime} \mathrm{O}{ }_{n}$ ).

Force constants for the hydrogen-bonded $\mathrm{CH}_{2}$ group were estimated by Krimm et al. ${ }^{8}$ from an approximate calculation on a $\mathrm{CH}_{2} \cdots \mathrm{O}$ system. It was found that the $\mathrm{CH}_{2}$ stretching frequencies observed at 2980 and 2800 $\mathrm{cm}^{-1}$ for the hydrogen-bonded group could be reproduced by changing the force constant $f(\mathrm{C}-\mathrm{H})$ by $+6 \%$ for the free $\mathrm{C}-\mathrm{H}$ and by $-6 \%$ for the hydrogen-bonded $\mathrm{C}-\mathrm{H}$, and that the $-14 \mathrm{~cm}^{-1}$ shift of the $\mathrm{CH}_{2}$ bending vibration could be explained by a $3 \%$ decrease in $f(\mathrm{HCH})$. We have repeated this calculation using the entire chain and the complete force field. Again a $6 \%$ change in $f(\mathrm{C}-\mathrm{H})$, i.e, $f^{\prime}(\mathrm{C}-\mathrm{H})=4.843$ and $f^{\prime}\left(\mathrm{C}-\mathrm{H}_{0}\right)=4.295$ $\mathrm{md} / \AA$, gives $\nu^{\prime}(\mathrm{C}-\mathrm{H})=2991$ and $\nu^{\prime}\left(\mathrm{C}-\mathrm{H}_{0}\right)=2801 \mathrm{~cm}^{-1}$, where the primed quantities pertain to the hydrogen-bonded $\mathrm{CH}_{2}$ group and $H_{0}$ is the hydrogen in $\mathrm{C}-\mathrm{H} \cdots \mathrm{O}$. The shift in the $\mathrm{CH}_{2}$ bending frequency is given by $\Delta \nu \cong 586(\Delta f(\mathrm{HCH}) / f(\mathrm{HCH}))$. The observed shift of $-14 \mathrm{~cm}^{-1}$ corresponds to a $2.4 \%$ decrease in $f(\mathrm{HCH})$. 
In evaluating the differences in force constants between PG II and PG I, as listed in Table I, the following facts should be kept in mind. First, the force constants were determined using a single-chain treatment, and they therefore include the effects of interchain $\mathrm{N}-\mathrm{H} \cdots \mathrm{O}=\mathrm{C}^{\prime}$ hydrogen bonding. These effects are probably different for PG II than for PG I. Second, the bond rotation angle $\varphi(\mathrm{N}-\mathrm{C})$ differs from PG II $\left(\varphi=-77^{\circ}\right)$ to PG I $\left(\varphi=-140^{\circ}\right)$. This can influence the force constants somewhat. ${ }^{15}$ Third, some force constants have large uncertainties due to the interdependence of force constants.

The differences in values of $f\left(\mathrm{C}^{\prime} \mathrm{NH}\right) \equiv f(\mathrm{CNH}), f\left(\mathrm{C}^{\prime}=\mathrm{O}\right.$ op $), f\left(\mathrm{C}^{\prime}-\right.$ $\left.\mathrm{N}, \mathrm{C}^{\prime} \mathrm{NH}\right) \equiv f(\mathrm{NC}, \mathrm{CNH})$, and $f\left(\mathrm{NC}^{\prime}=\mathrm{O}, \mathrm{C}^{\prime} \mathrm{NH}\right)$ between $\mathrm{PG}$ I and PG II are probably due to differences in hydrogen bonding, which directly affect these force constants. The difference in $f\left(\mathrm{C}^{\prime} \mathrm{NC}\right)$ may be due to the same reason, since the $\mathrm{C}^{\prime} \mathrm{NC}$ deformation vibration is considerably coupled with the $\mathrm{H} \cdots \mathrm{O}$ stretching vibration, as was seen in the case of $\mathrm{PG} \mathrm{I}^{5}$ The difference in $f(\mathrm{NCH})$ and in $f(\mathrm{NC}, \mathrm{NCH})$ between PG I and PG II may be due to the different bond rotation angles $\varphi(\mathrm{N}-\mathrm{C})$. Actually, the diagonal term $f(\mathrm{NCH})$ should itself not be very different, and some other force constants, probably interaction constants between the $\mathrm{CH}_{2}$ group and the neighboring $\mathrm{NH}$ group, perhaps account for the effects of rotation about the $\mathrm{N}-\mathrm{C}$ bond. Unfortunately, not enough experimental data were available, and we had to assume the same values for most of the interaction constants of both PG I and PG II. The force constant $f(\mathrm{HCH})$ of PG II is smaller than that of PG I by $\sim 10 \%$. As mentioned above, the effect of hydrogen bonding on $f(\mathrm{HCH})$ accounts for only a $2.4 \%$ decrease. The remainder may be due to some difference in the environment of the $\mathrm{CH}_{2}$ group itself between PG I and PG II, for example, associated with intermolecular interactions.

Some differences in the force constants between PG I or PG II and the nylons may arise from the same reasons as given above. In this case, the correlation of force constants also enters in. For example, for the nylons $f\left(\mathrm{C}^{\prime} \mathrm{NH}\right)=0.848$ and $f(\mathrm{CNH})=0.306$, the average of which is 0.572 and is very close to the value for PG II.

Two problems may bear further examination. One concerns the assignment of amide III of $+\mathrm{NHCH}_{2} \mathrm{C}^{\prime} \mathrm{O}+{ }_{n}$. Three possible assignments for the three bands observed at 1283, 1261, and $1247 \mathrm{~cm}^{-1}$ suggest themselves, as shown in Table III. Assignment 1 is the one used in the present calculation. The force constants were also determined for assignments 2 and 3. For assignment $2 f\left(\mathrm{C}^{\prime} \mathrm{N}\right)=6.949, f\left(\mathrm{C}^{\prime} \mathrm{NH}\right) \equiv f(\mathrm{CNH})=0.557$, and $f\left(\mathrm{C}^{\prime} \mathrm{N}, \mathrm{C}^{\prime} \mathrm{NH}\right) \equiv f(\mathrm{NC}, \mathrm{CNH})=0.251$ were obtained, and for assignment 3 these constants were $6.597,0.573$, and 0.211 , respectively. There are reasons to believe that the first assignment is the most probable one. First, in the infrared spectra of the model compounds $\mathrm{CH}_{3} \mathrm{CO}$ $\left(\mathrm{NHCH}_{2} \mathrm{CO}\right)_{n} \mathrm{NHCH}_{3}$ and $\mathrm{CH}_{3} \mathrm{CO}\left(\mathrm{NHCH}_{2} \mathrm{CO}\right)_{n} \mathrm{NHC}_{2} \mathrm{H}_{5},{ }^{16,17}$ two amide III bands are observed at ca 1305 and $1285 \mathrm{~cm}^{-1}$. In most cases the amide III frequency of the $A$ species is calculated at a lower value than 
TABLE III

Possible Assignments ${ }^{2}$ for Amide III of $\left(\mathrm{NHCH}_{2} \mathrm{C}^{\prime} \mathrm{O}\right)_{n}$

\begin{tabular}{|c|c|c|}
\hline & A & $\mathrm{E}$ \\
\hline \multicolumn{3}{|c|}{ Assignment 1} \\
\hline Amide III & $\int\left(\begin{array}{l}1283(\mathrm{IR}) \\
1283(\mathrm{R})\end{array}\right.$ & $?$ \\
\hline \multirow[t]{2}{*}{$\mathrm{CH}_{2}$ twist. } & $\left\{\begin{array}{l}1249(\mathrm{IR}) \\
1244(\mathrm{R})\end{array}\right.$ & $1261(\mathrm{R})$ \\
\hline & Assignment $\mathscr{Z}$ & \\
\hline Amide III & $(1261(\mathrm{R})$ & $\left(\begin{array}{l}1283(\mathrm{IR}) \\
1283(\mathrm{R})\end{array}\right.$ \\
\hline \multirow[t]{2}{*}{$\mathrm{CH}_{2}$ twist. } & $\left\{\begin{array}{l}1249(\mathrm{IR}) \\
1244(\mathrm{R})\end{array}\right.$ & $\left(\begin{array}{l}1249(\mathrm{IR}) \\
1244(\mathrm{R})\end{array}\right.$ \\
\hline & Assignment 3 & \\
\hline Amide III & $\left(\begin{array}{l}1283(\mathrm{IR}) \\
1283(\mathrm{R})\end{array}\right.$ & $\left(\begin{array}{l}1283(\mathrm{IR}) \\
1283(\mathrm{R})\end{array}\right.$ \\
\hline $\mathrm{CH}_{2}$ twist. & $\left\{\begin{array}{l}1249(\mathrm{IR}) \\
1244(\mathrm{R})\end{array}\right.$ & $1261(\mathrm{R})$ \\
\hline
\end{tabular}

a IR, observed infrared bands; R, observed Raman bands.

that of the E species. Accordingly, the $1283 \mathrm{~cm}^{-1}$ band of PG II should be assigned to the $A$ species rather than the $\mathrm{E}$ species. Secondly the calculated frequencies using the force constants based on assignments 2 or 3 are not in as good agreement with the observed values as for assignment 1 . While we therefore favor it, more experimental evidence may still be needed in order to establish this assignment conclusively.

The second problem is that we could not determine many of the force constants for the skeletal vibrations, and we had to assume approximate values for these. This problem is not particular to polyglycine, but rather is common to all molecules of relatively large size. Experimental data on frequency shifts due to isotopic substitution of skeletal atoms is required in order to solve the problem, since isotopic substitution of the pendant atoms does not yield observably different skeletal frequencies.

This work was supported by grants GP-10922 and GB-15682 from the National Science Foundation. A postdoctoral fellowship from the Macromolecular Research Center at the University of Michigan to one of us (Y.A.) is gratefully acknowledged.

\section{References}

1. T. Miyazawa, in Poly- $\alpha-A$ mino Acids, G. D. Fasman, Ed., Marcel Dekker, Inc., New York, 1967.

2. T. Miyazawa and M. Tsuchida, unpublished results, 1966 (cited as Ref. 44a in Ref. 1).

3. E. W. Small, B. Fanconi, and W. L. Peticolas, J. Chem. Phys., 52, 4369 (1970).

4. R. D. Singh and V. D. Gupta, Spectrochim. Acta, 27A, 385 (1971).

5. Y. Abe and S. Krimm, Biopolymers, 11, 1817 (1972).

6. F. H. C. Crick and A. Rich, Nature, 176, 780 (1955). 
7. G. N. Ramachandran, V. Sasisekharan, and C. Ramakrishnan, Biochim. Biophys. Acta, 112, 168 (1966).

8. S. Krimm, K. Kuroiwa, and T. Rebane, in Conformation of Biopolymers, G. N. Ramachandran, Ed., Academic Press, New York, 1967, p. 439.

9. S. Krimm and K. Kuroiwa, Biopolymers, 6, 401 (1968).

10. S. Krimm, Nature, 212, 1482 (1966).

11. G. N. Ramachandran and V. Sasisekharan, in Conformation of Biopolymers, G. N. Ramachandran, Ed., Academic Press, New York, 1967, p. 429.

12. T. Miyazawa, Y. Ideguchi, and K. Fukushima, J. Chem. Phys., 38, 2709 (1963).

13. S. Suzuki, Y. Iwashita, T. Shimanouchi, and M. Tsuboi, Biopolymers, 4, 337 (1966).

14. J. Jakeš and S. Krimm, Spectrochim. Acta, 27A, 19 (1971).

15. J. Jakeš and S. Krimm, Spectrochim. Acla, 27A, 35 (1971).

16. Y. Koyama and T. Shimanouchi, Biopolymers, 6, 1037 (1968).

17. M. Avignon and C. Garrigou-Lagrange, Spectrochim. Acta, 27A, 297 (1971).

Received February 18, 1972 